\title{
PENGARUH EKSTRAK DAUN GEDI (Abelmoschus manihot L.) TERHADAP GAMBARAN HISTOPATOLOGI AORTA TIKUS WISTAR DENGAN DIET ATEROGENIK
}

\author{
${ }^{1}$ Nadya Nadiratika Papodi \\ ${ }^{2}$ Meilany Durry \\ ${ }^{2}$ Carla Kairupan \\ ${ }^{1}$ Kandidat Skripsi Fakultas Kedokteran Universitas Sam Ratulangi Manado \\ ${ }^{2}$ Bagian Patologi Anatomi, Fakultas Kedokteran Universitas Sam Ratulangi \\ Manado
}

Email: nadyapapodi@ymail.com

\begin{abstract}
High blood cholesterol is a major risk factor for atherosclerosis. Gedi plants contain polyphenolic compounds that can lowering blood cholesterol levels. This study aimed to find out the effect of gedi (Abelmoschus manihot L) leaves extract on histopatologic features of aorta of those wistar rats, which had been administered an atherogenic diet. This was an experimental study on animal using 20 Wistar rats as samples. The rats were divided into 4 different groups, 5 rats for each group. Negative control group was fed only pelet, positive control group was fed pork fat as much as $2 \mathrm{ml} /$ day, group C was fed on pork fat and gedi leaf extract, and group D was fed on pork fat then continued with gedi leaf extract. The results indicated that administration of $30 \mathrm{mg}$ gedi leaf extract showed a histopathologic feature which is decreasing of foam cells. Conclusion: Microscopically, aorta of those rats fed on pork lard diet showed a number of foam cells in tunica intima and media whereas the rats that were fed on pork lard along with gedi leaf extract, generally there were no foam cells, but there aresome parts which contain few foam cells. On the group of Wistar rats which were fed on pork lard, continued with gedi leaf extract showed less foam cells compared to the positive control group.
\end{abstract}

Keywords: Gedi leaf extract, pork lard, foam cell.

\begin{abstract}
Abstrak: Kadar kolesterol darah yang tinggi merupakan faktor risiko utama terjadinya aterosklerosis. Tumbuhan gedi mengandung senyawa polifenol yang dapat menurunkan kadar kolesterol darah. Penelitian ini bertujuan untuk mengetahui pengaruh pemberian ekstrak daun gedi terhadap gambaran histopatologi aorta tikus wistar dengan diet aterogenik. Hewan uji yang digunakan berupa 20 ekor tikus Wistar yang dibagi ke dalam 4 kelompok, masing-masing kelompok terdiri dari 5 ekor tikus. Kelompok kontrol negatif hanya diberikan pelet biasa, kelompok kontrol positif diberikan diet lemak babi $2 \mathrm{ml} /$ hari, kelompok $\mathrm{C}$ diberikan diet lemak babi bersamaan dengan ekstrak daun gedi, dan kelompok D diberikan lemak babi kemudian dilanjutkan dengan pemberian ekstrak daun gedi. Hasil penelitian memperlihatkan bahwa pemberian ekstrak daun gedi $30 \mathrm{mg}$ mampu memberikan gambaran histopatologi aorta berupa berkurangnya jumlah sel busa. Simpulan: Secara mikroskopik, aorta tikus wistar yang diberi lemak babi menunjukkan adanya penumpukan sel-sel busa pada tunika intima dan media, sedangkan pada aorta tikus wistar yang diberi lemak babi bersamaan dengan ekstrak daun gedi maupun yang dilanjutkan dengan ekstrak daun gedi ditemukan berkurangnya jumlah sel-sel busa.
\end{abstract}

Kata Kunci : Ekstrak daun gedi, Lemak babi, Sel busa.

Tumbuhan gedi (Abelmoschus manihot L.) yang dikenal masyarakat Sulawesi Utara sebagai sayuran, ternyata juga digunakan sebagai tanaman yang berkhasiat obat. Tanaman ini terdiri dari 15 spesies, namun hanya 3 spesies yang dikenal di Indonesia yaitu: Abelmoschus manihot, Abelmoschus moschatus dan Abelmoschus esculentus. Di Sulawesi, dikenal dua 
macam gedi yaitu gedi merah dan gedi hijau. Selain sebagai sayuran tanaman ini digunakan masyarakat untuk mengobati sakit ginjal, maag, dan untuk menurunkan kolesterol darah. Daun gedi mengandung senyawa berkhasiat polifenol, yaitu: tanin terkondensasi, fenolik dan flavonoid yang diketahui dapat menurunkan kolesterol darah. ${ }^{1,2}$

Kadar kolesterol darah yang tinggi merupakan faktor risiko utama terjadinya aterosklerosis. Kolesterol LDL (Low Density Lipoprotein) yang teroksidasi menyebabkan terjadinya respon inflamasi pada endotel. Makrofag akan menelan LDL yang teroksidasi hingga akhirnya akan membentuk fatty streak yang terdiri dari sel-sel busa atau makrofag yang tampak berbuih. Fatty streak merupakan lesi awal terbentuknya aterosklerosis. ${ }^{3}$

Konsumsi pakan tinggi lemak dapat meningkatkan kadar kolesterol plasma. Lemak babi merupakan bahan makanan yang dapat meningkatkan kadar kolesteol. Lemak babi mengandung asam lemak jenuh ganda yang relatif lebih besar dari pada lemak sapi dan lemak ayam. ${ }^{4}$ Keadaan hiperkolesterolemia dapat menyebabkan disfungsi endotel. Terganggunya fungsi sel endotel menyebabkan permeabilitas endotel jadi meningkat sehingga LDL dapat masuk ke dalam intima. LDL kemudian akan teroksidasi dan kontak dengan makrofag, sehingga membentuk sel busa. Berdasarkan pengalaman empirik dan beberapa kepustakaan, penulis tertarik untuk melakukan penelitian mengenai penghambatan dan pencegahan terjadinya fatty streak yang merupakan lesi awal dari aterosklerosis pada tikus wistar dengan diet aterogenik.

Tujuan penelitian ini adalah untuk mengetahui pengaruh pemberian ekstrak daun gedi (Abelmoschus manihot L.) terhadap gambaran histopatologi aorta tikus wistar dengan diet aterogenik.

\section{METODE PENELITIAN}

Jenis penelitian ini dilakukan dengan menggunakan metode eksperimental yang dilaksanakan di Laboratorium Riset Biomedik dan Patologi Anatomi Fakultas Kedokteran Universitas Sam Ratulangi pada Oktober-Januari 2013. Subjek penelitian yang digunakan adalah 20 ekor tikus wistar dewasa.

\section{Bahan}

Daun gedi yang digunakan dalam penelitian ini ialah daun gedi muda yang diekstraksi menggunakkan teknik ekstraksi maserasi. Gedi diidentifikasi oleh Jurusan Biologi FMIPA Universitas Sam Ratulangi Manado.

\section{Prosedur Penelitian}

Tikus wistar dipelihara dalam wadah yang ditaburi dedak padi dan ditutup dengan kawat kasa selama 1 bulan agar tikus wistar beradaptasi dengan tempat yang baru. Selama pemeliharaan tikus wistar diberi makan dan diberi minum dari botol yang diberi pipet. Lemak babi diberikan sebanyak 2ml/ekor dengan menggunakan NGT. Berdasarkan penelitian sebelumnya, dosis ini dapat memicu lesi aterosklerosis. Dosis daun gedi yang akan diberikan adalah $30 \mathrm{mg}$. Berdasarkan penelitian sebelumnya, dosis daun gedi tersebut mampu memberikan perubahan histologik pada aorta tikus wistar. ${ }^{4}$

\section{Perlakuan Hewan Uji}

Hewan uji coba berjumlah 20 ekor dibagi menjadi 4 kelompok perlakuan :

Kelompok A : Terdiri atas 5 ekor tikus sebagai kontrol negatif yang hanya diberikan makan pelet biasa dan minum air. Sebelum di terminasi dilakukan pengukuran berat badan dan pemeriksaan kadar kolesterol darah. 
Kelompok B : Terdiri atas 5 ekor tikus sebagai kontrol positif yang diberikan lemak babi selama 14 hari dan ada yang dilanjutkan hingga 28 hari. Sebelum diterminasi dilakukan pengukuran berat badan dan pemeriksaan kadar kolesterol darah.

Kelompok C : Terdiri atas 5 ekor tikus yang diberikan lemak babi bersamaan dengan pemberian ekstrak daun gedi selama 14 hari dan ada yang dilanjutkan hingga 28 hari. Sebelum di terminasi dilakukan pengukuran berat badan dan pemeriksaan kadar kolesterol darah.

Kelompok D : Terdiri dari 5 ekor wistar yang diberikan lemak babi selama 14 hari dan ada yang dilanjutkan hingga 28 hari, kemudian dilanjutkan dengan pemberian ekstrak daun gedi selama 7 hari. Sebelum di terminasi dilakukan pengukuran berat badan dan pemeriksaan kadar kolesterol darah.

Penelitian ini dilakukan selama 35 hari. Sebelum dilakukan perlakuan, masing-masing kelompok perlakuan diukur terlebih dahulu berat badannya. Pada hari ke-36, dilakukan pengukuran berat badan dan kolesterol sebelum akhirnya di terminasi. Pemeriksaan kadar kolesterol dilakukan dengan cara mengambil darah dari ekor tikus lalu di teteskan pada stik alat pemeriksaan kolesterol, kemudian diambil aorta ascendensnya, lalu dibuat preparat untuk melihat perubahan histologi aorta.

\section{HASIL PENELITIAN}

\section{Gambaran Mikroskopik Aorta Tikus Wistar (14 hari).}

\section{Tikus wistar kelompok kontrol negatif}

Gambaran mikroskopik aorta tikus wistar kelompok kontrol tanpa pemberian lemak babi menunjukkan lapisan aorta yang normal. Tampak aorta yang terdiri dari tunika intima, media, dan adventitia. Pada pembuluh darah (arteri) normal, tunika intimanya terdiri atas satu lapisan sel endotel dengan jaringan ikat sub endotel minimal dibawahnya sel dipisahkan dari tunika media oleh suatu membran elastis padat yang disebut lamina elastika interna. Tunika media terdiri dari serabut-serabut elastis yang sangat banyak, dan sel-sel otot polos. Tidak terlihat adanya sel-sel busa baik pada tunika intima maupun tunika media.

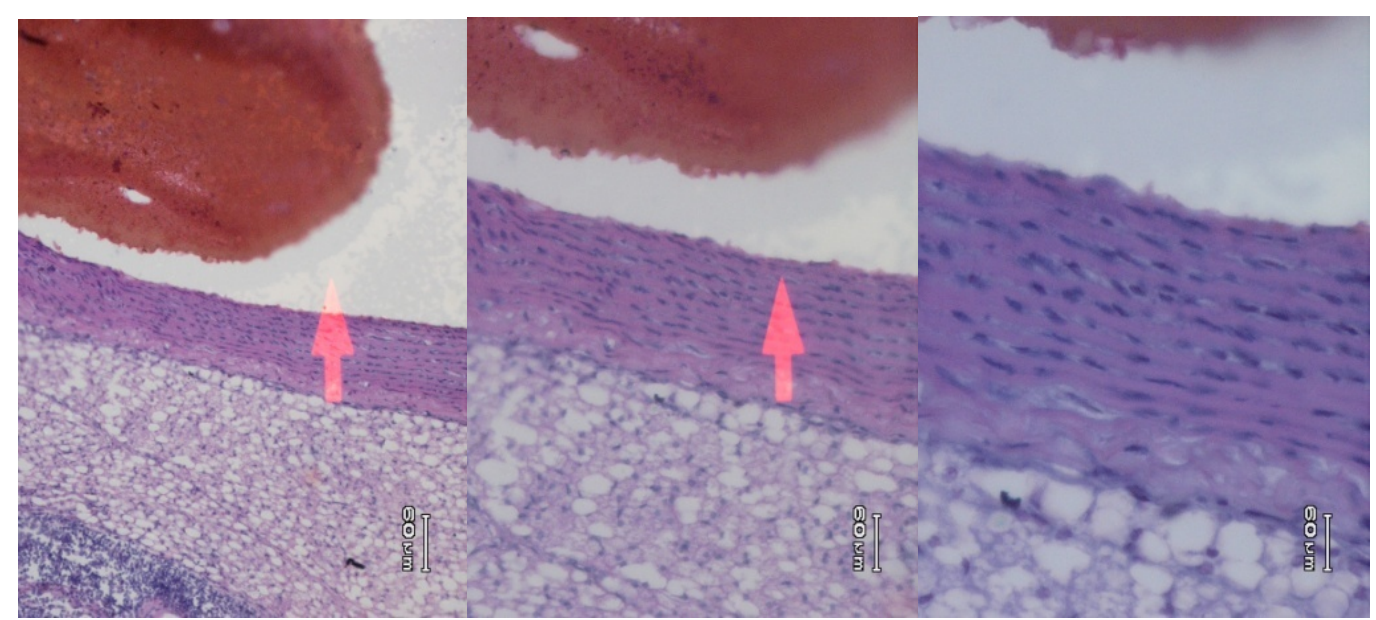

Gambar 8. Gambaran mikroskopik aorta kelompok kontrol negatif 14 hari 


\section{Tikus Wistar Kelompok Kontrol Positif}

Gambaran mikroskopik tikus perlakuan yang diberikan lemak babi dengan dosis 2ml/hari pada tikus B1 menunjukkan sel-sel busa yang banyak terletak pada tunika intima dan media.
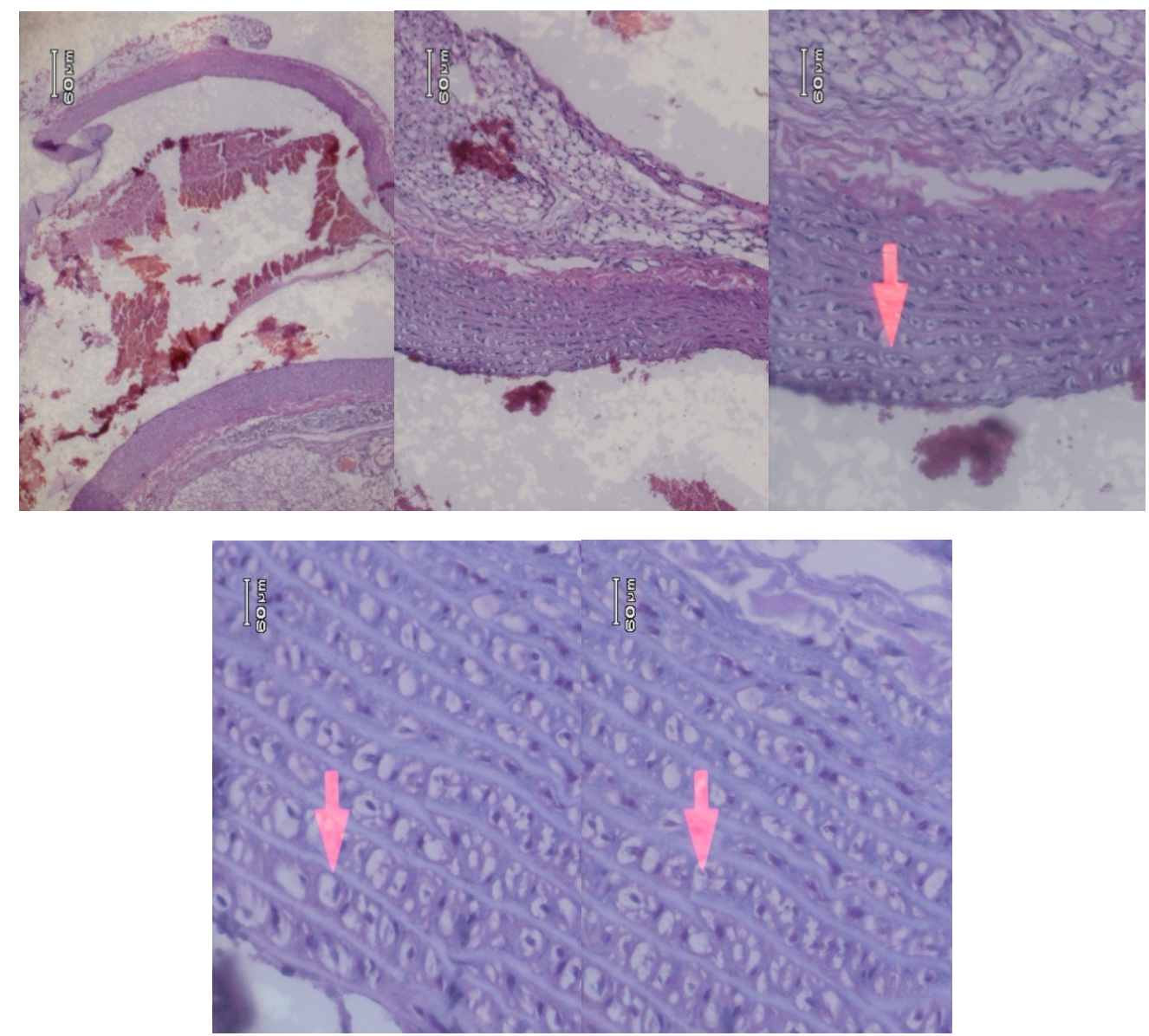

Gambar 9. Gambaran mikroskopik aorta kelompok kontrol positif 14 hari.

\section{Tikus Wistar Kelompok Pemberian Lemak Babi bersamaan dengan pemberian ekstrak daun gedi.}

Gambaran mikroskopik aorta tikus perlakuan yang diberikan lemak babi $2 \mathrm{ml} / \mathrm{hari}$ bersamaan dengan ekstrak daun gedi $1 \mathrm{ml} /$ hari, menunjukkan lapisan aorta yang normal, dan ada beberapa bagian yang menunjukkan adanya sel busa pada tunika intima dan tunika media. 

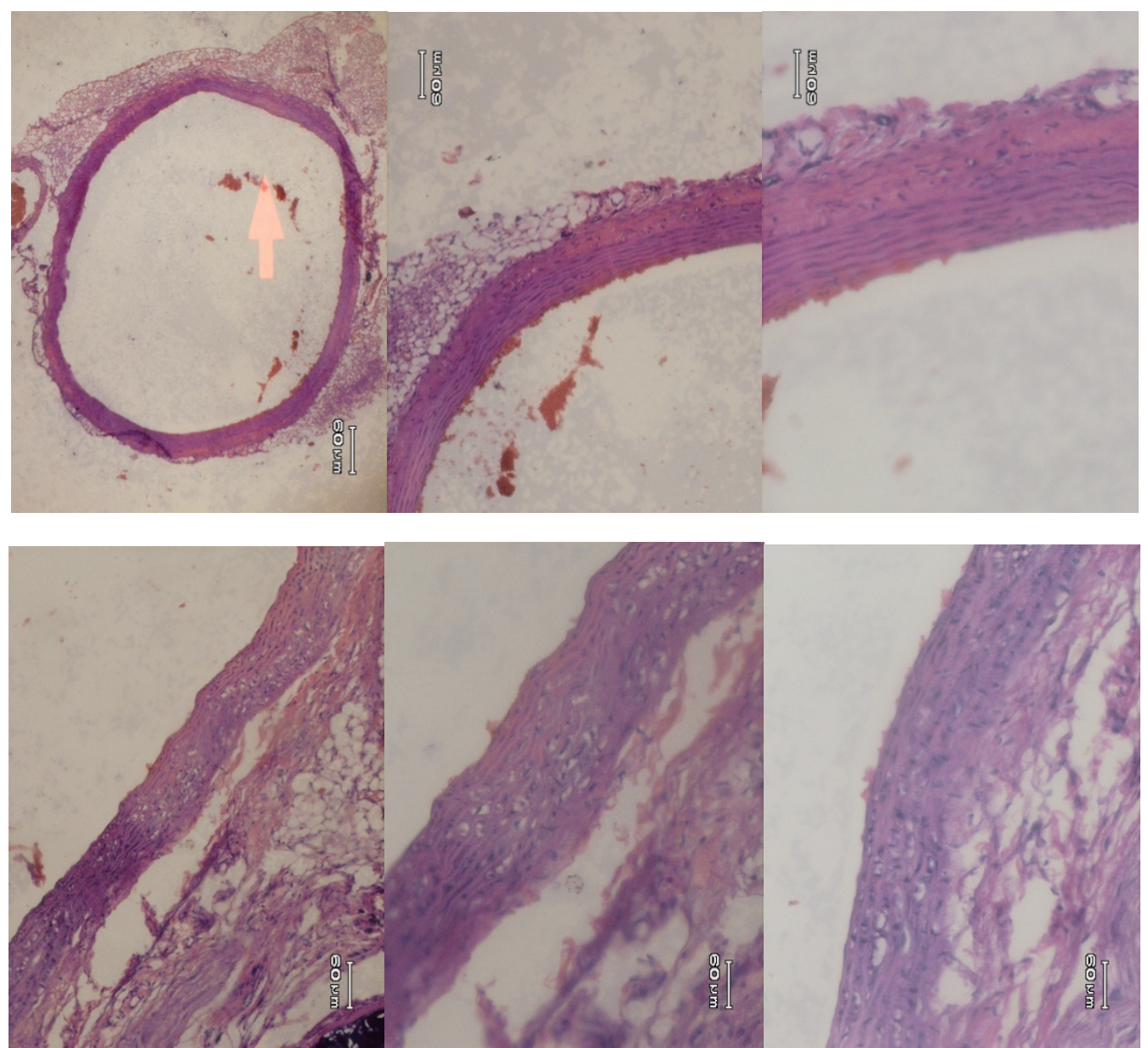

Gambar 10. Gambaran mikroskopik aorta kelompok pemberian lemak babi bersamaan dengan ekstrak daun gedi selama 14 hari.

\section{Tikus wistar kelompok pemberian lemak babi dilanjutkan dengan ekstrak daun gedi.}

Gambaran mikroskopik aorta tikus perlakuan yang diberikan lemak babi 2ml/hari lalu dilanjutkkan dengan pemberian ekstrak daun gedi $1 \mathrm{ml} /$ hari selama 7 hari, menunjukkan lapisan aorta yang masih terdapat sel-sel busa di bagian-bagian tertentu.

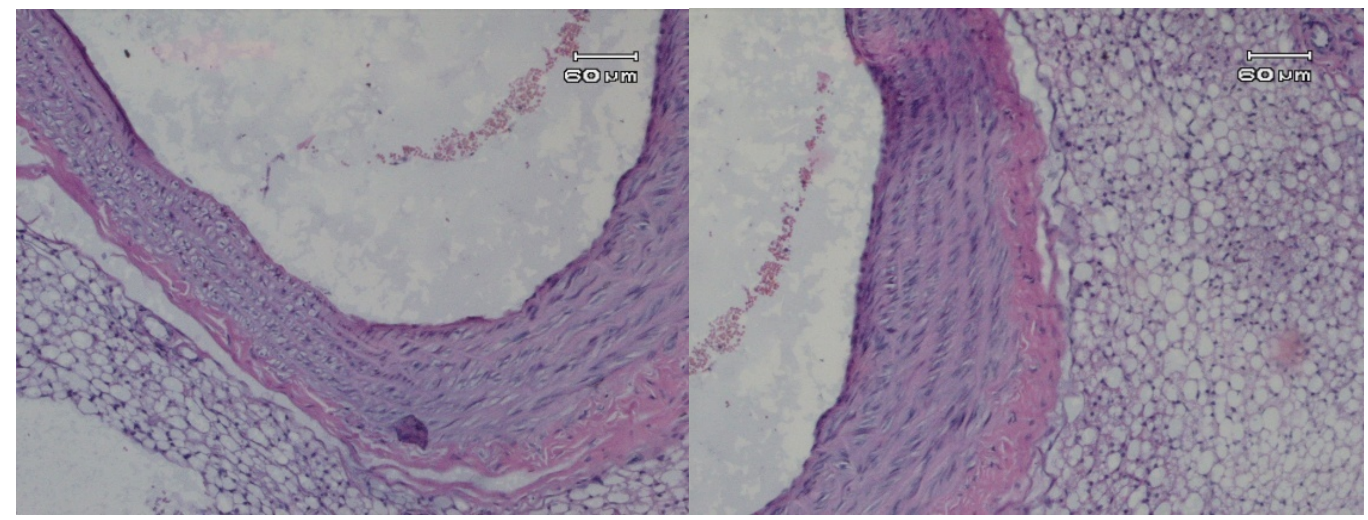




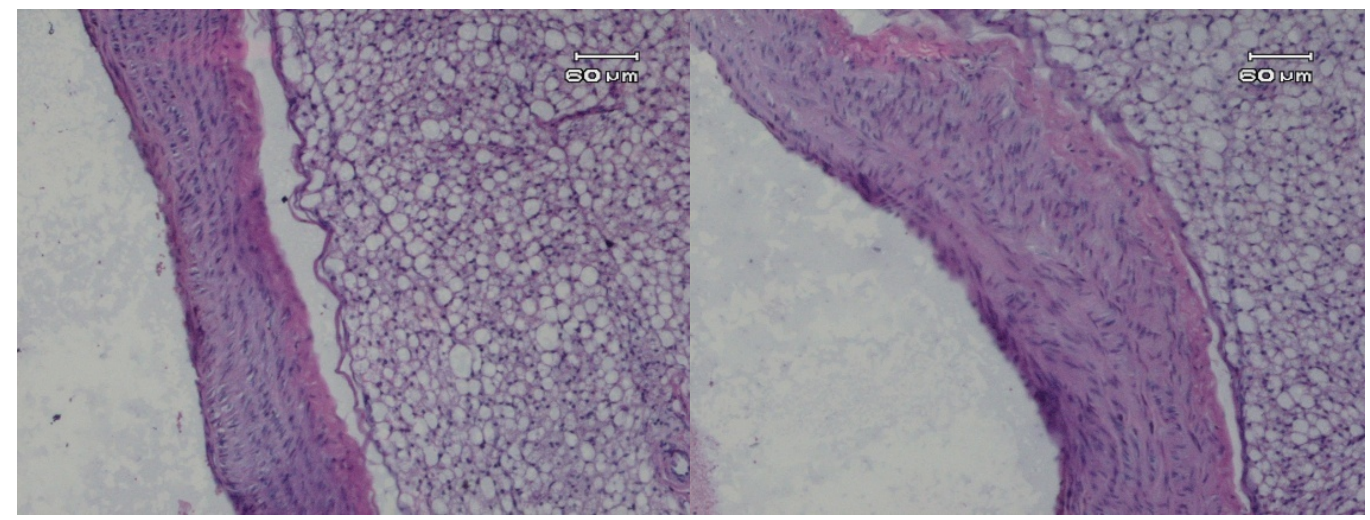

Gambar 11. Gambaran mikroskopik kelompok D yang diberikan lemak babi kemudian dilanjutkan dengan ekstrak daun gedi selama 7 hari.

\section{Gambaran Mikroskopik Aorta Tikus Wistar ( 28 hari )}

\section{Tikus wistar kelompok kontrol negatif A3}

Pada kelompok tikus wistar kontrol negatif, gambaran mikroskopik aorta tikus wistar menunjukkan lapisan yang normal, yaitu tunika intima, tunika media dan tunika adventisia.
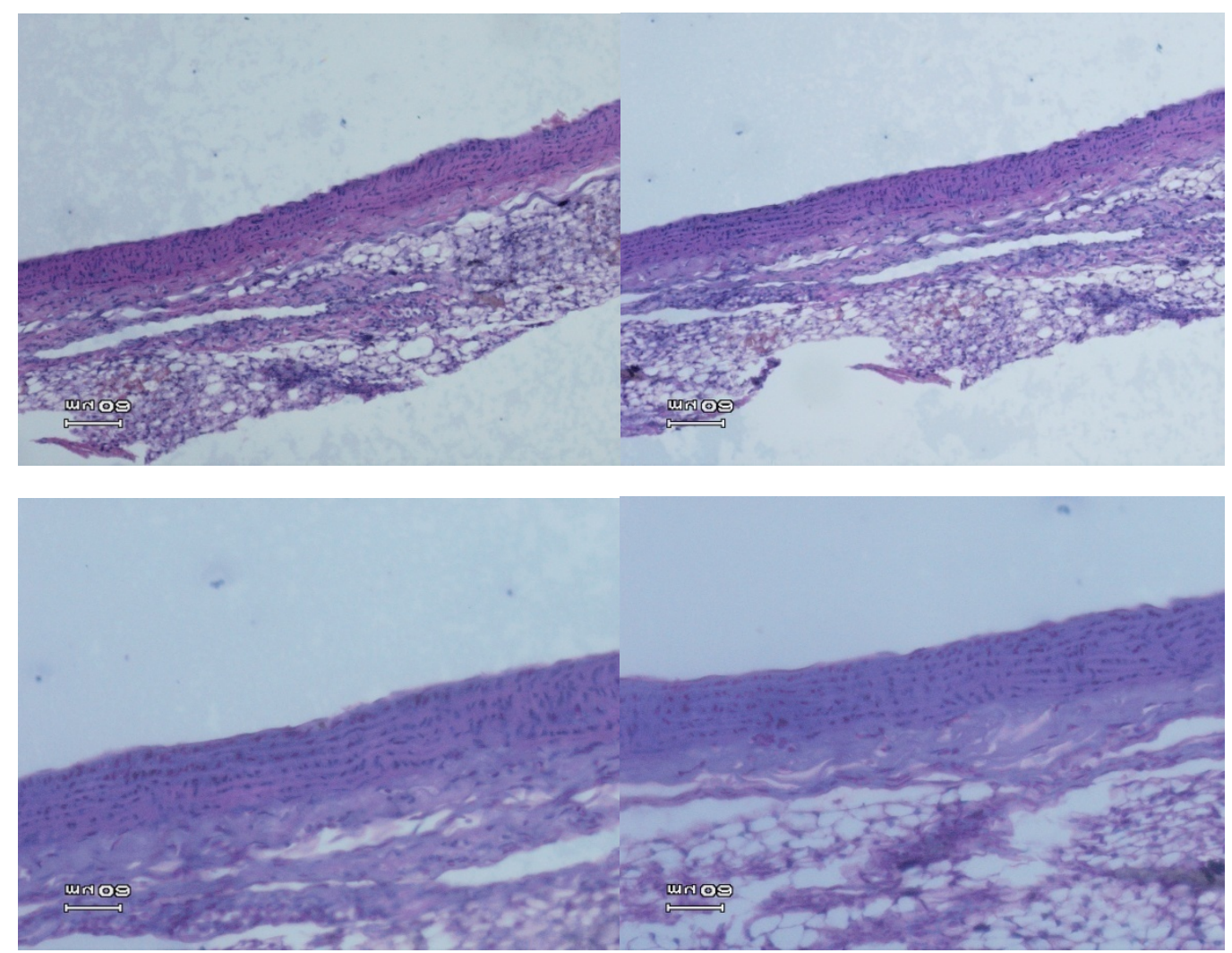

Gambar 14. Gambaran mikroskopik aorta kelompok kontrol negatif 28 hari. 


\section{Tikus Wistar Kelompok Pemberian Lemak Babi}

Pada kelompok tikus wistar dengan diet lemak babi selama 28 hari, gambaran mikroskopik aorta tikus wistar menunjukkan adanya sel-sel busa yang terlihat pada tunika intima dan tunika media.

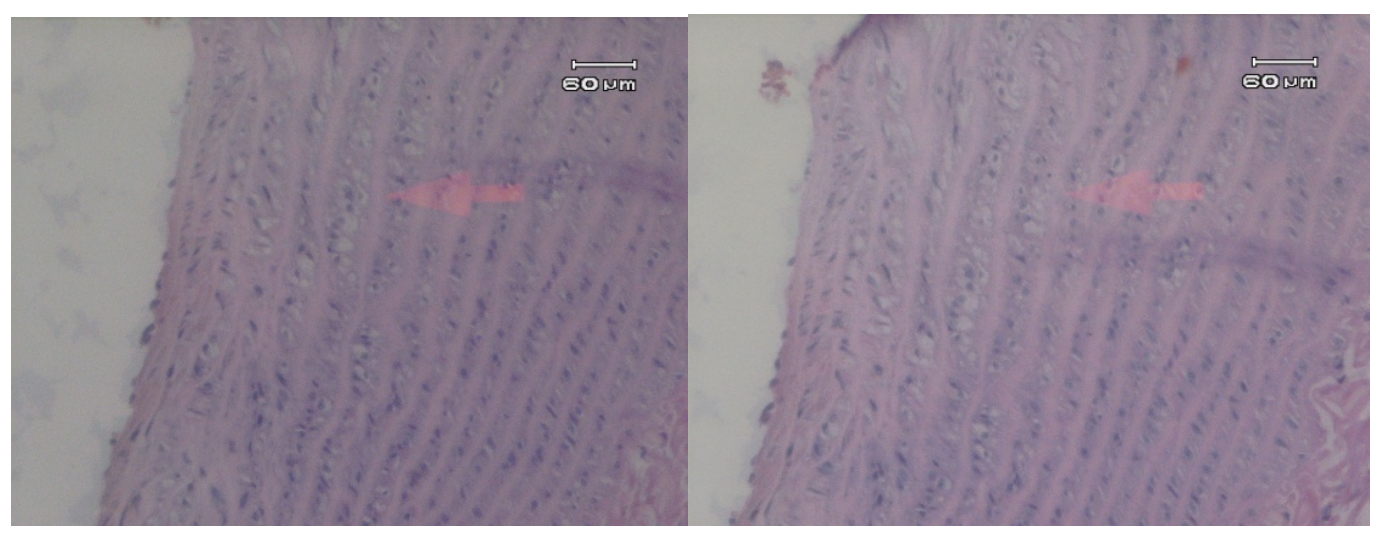

Gambar 15. Gambaran mikroskopik aorta kelompok kontrol positif 28 hari.

\section{Tikus Wistar Kelompok C1}

Gambaran mikroskopik aorta tikus perlakuan yang diberikan lemak babi $2 \mathrm{ml} /$ hari bersamaan dengan ekstrak daun gedi $1 \mathrm{ml} /$ hari, menunjukkan lapisan aorta yang normal, dan ada beberapa bagian yang menunjukkan adanya sel busa pada tunika intima dan tunika media.
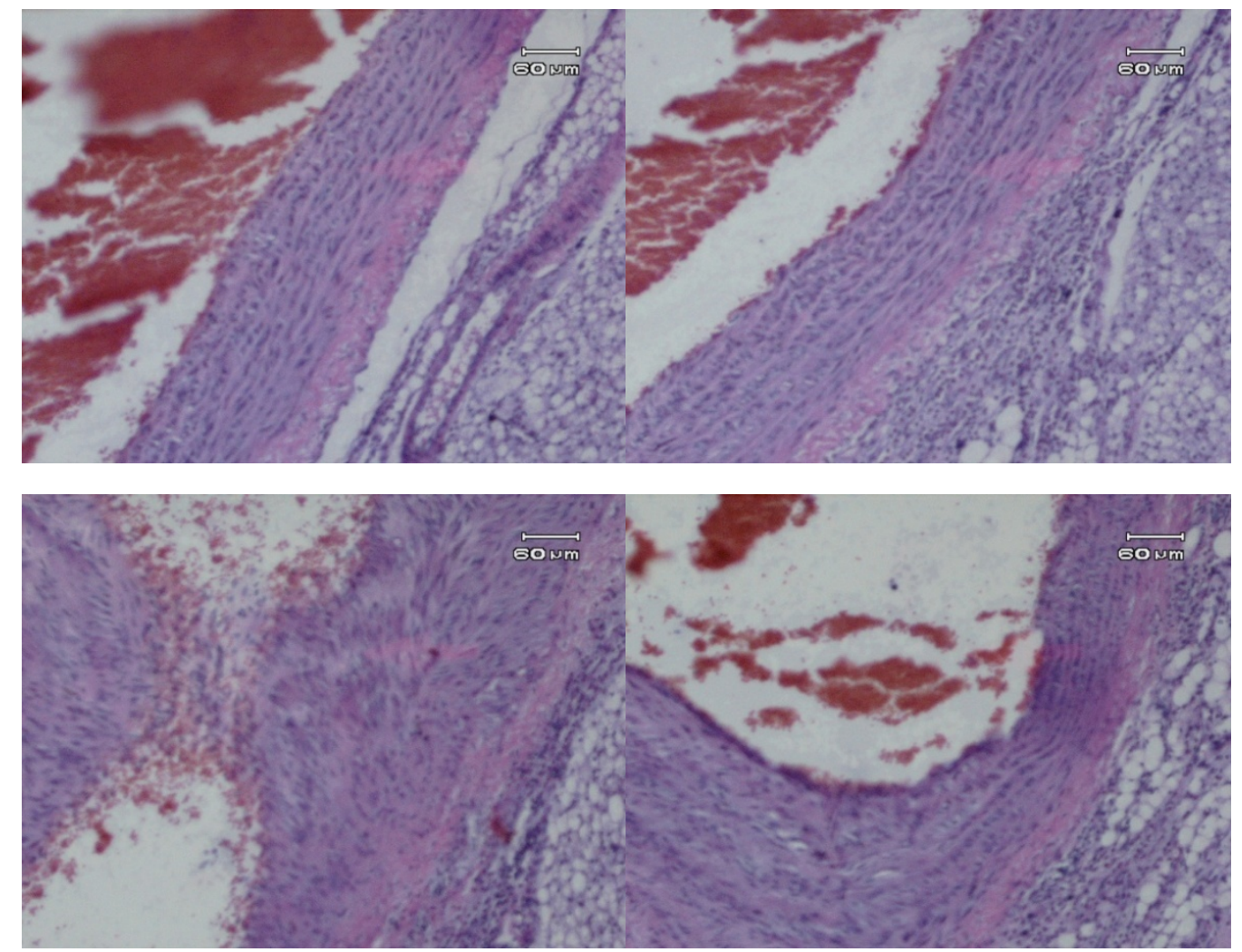
Gambar 16. Gambaran mikroskopik aorta kelompok dengan pemberian lemak babi bersamaan dengan daun gedi selama 28 hari.

\section{Tikus Wistar Kelompok C3}

Pada kelompok tikus wistar dengan pemberian lemak babi bersamaan dengan ekstrak daun gedi selama 28 hari, menunjukkan gambaran mikroskopik aorta yang normal dan sebagian masih terlihat adanya sel-sel busa.
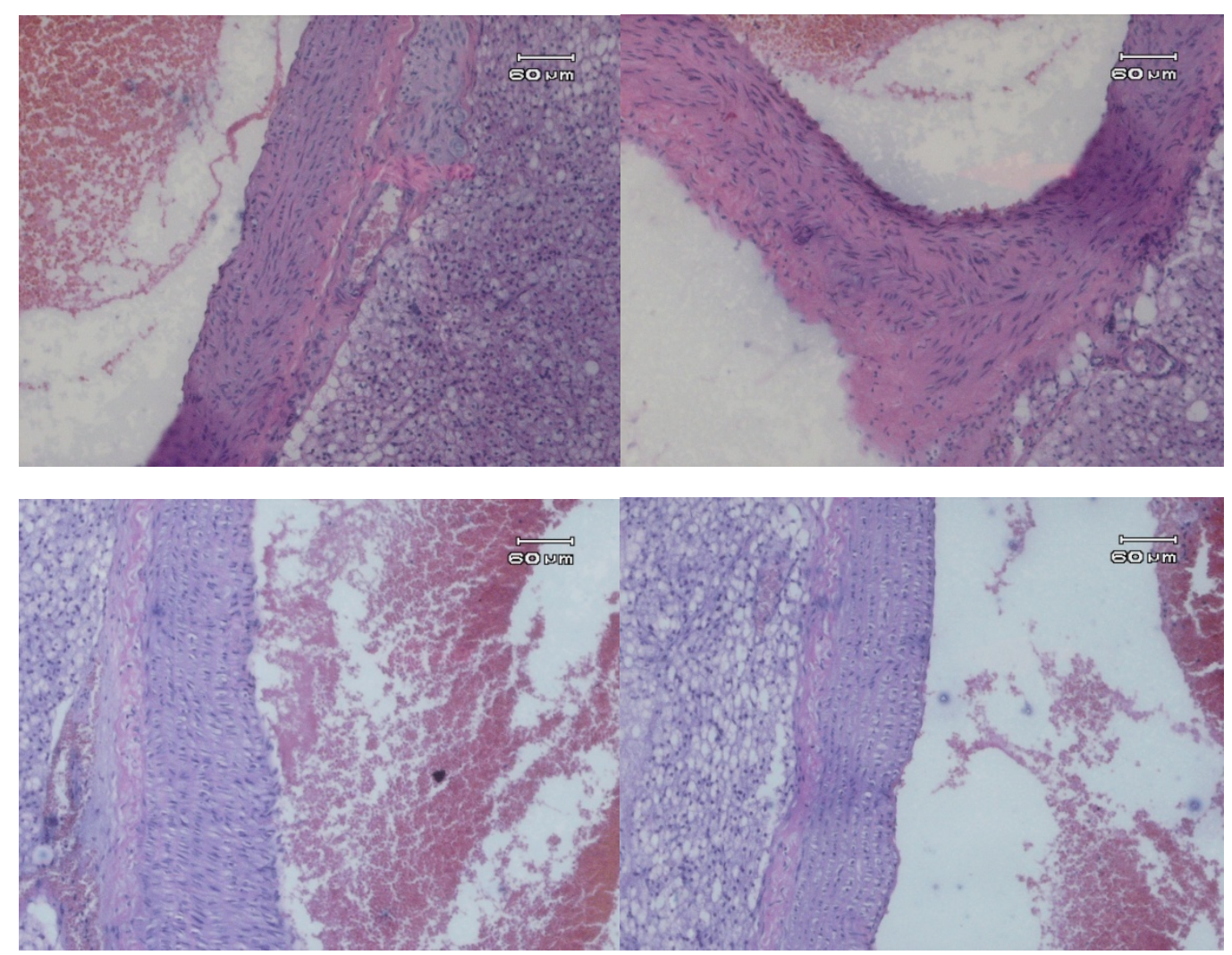

Gambar 17. Gambaran mikroskopik aorta kelompok pemberian lemak babi bersamaan dengan daun gedi selama 28 hari.

\section{Tikus wistar kelompok D2}

Pada kelompok tikus wistar dengan diet lemak babi selama 28 hari dan dilanjutkan dengan pemberian ekstrak daun gedi selama 7 hari, gambaran mikroskopik aorta tikus wistar masih terdapat sel-sel busa, namun ada juga beberapa bagian yang telah menunjukkan efek terapi berupa berkurangnya selsel busa. 

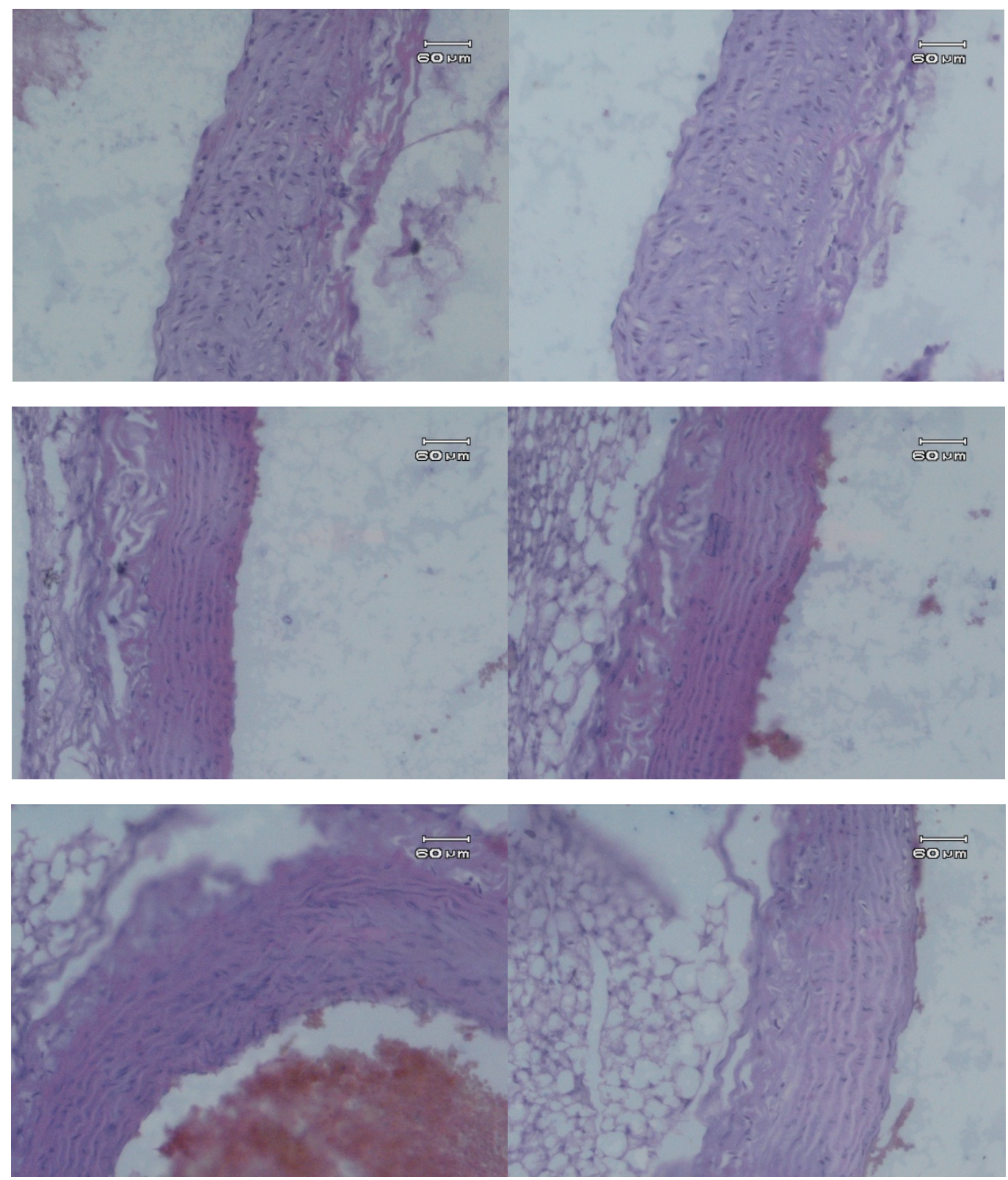

Gambar 18. Gambaran mikroskopik aorta tikus D2.

\section{Tikus wistar kelompok D3}

Pada kelompok tikus wistar dengan pemberian lemak babi selama 28 hari dan dilanjutkkan dengan pemberian ekstrak daun gedi selama 7 hari, gambaran mikroskopik aorta tikus masih memperlihatkan adanya sel busa, namun dalam jumlah yang lebih sedikit 


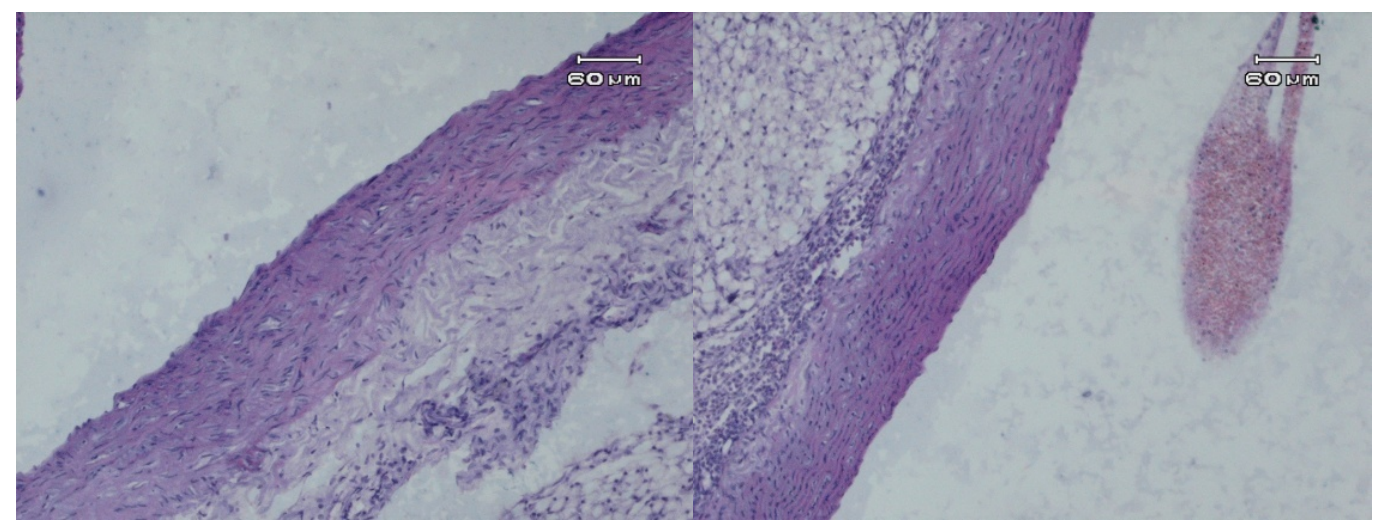

Gambar 19. Gambaran mikroskopik aorta tikus D3.

\section{BAHASAN}

Secara umum, hasil penelitian ini menunjukkan adanya perbedaan gambaran histologi aorta tikus wistar pada kelompok kontrol negatif, kelompok perlakuan diet aterogenik dan kelompok dengan pemberian ekstrak daun gedi. Pada pengukuran berat badan semua kelompok kontrol maupun perlakuan, didapati bahwa terjadi penurunan berat badan. Gambaran makroskopik dari masing-masing kelompok tidak menunjukkan perbedaan yang menonjol. Hal ini kemungkinan disebabkan oleh waktu perlakuan yang tergolong cukup singkat.

Pada tikus kelompok kontrol positif dengan pemberian lemak babi dengan dosis $2 \mathrm{ml} / \mathrm{hari}$ selama 2 minggu menunjukkan perubahan berupa adanya sel-sel busa yang cukup banyak pada tunika intima dan tunika media sedangkan pada kelompok tikus wistar yang diberikan lemak babi selama 28 hari menunjukan jumlah sel busa yang lebih sedikit. Gambaran ini sesuai dengan kepustakaan yang menyebutkan bahwa asupan kolesterol yang tinggi pada makanan menyebabkan hiperlipidemia termasuk hiperkolesterol. Sel busa dapat terbentuk pada hiperlipidemia yang kronis. Pada hiperlipidemia kronis terjadi penumpukan LDL, yang dapat teroksidasi oleh karena pengaruh dari radikal bebas. LDL yang teroksidasi ini akan ditelan oleh makrofag sehingga membentuk sel busa. ${ }^{6}$ Dalam penelitian ini, pemberian diet lemak babi selama 14 hari telah memicu terbentuknya sel-sel busa pada tunika intima dan tunika media.

Pada gambaran mikroskopik aorta tikus dengan pemberian lemak babi $2 \mathrm{ml} / \mathrm{hari}$ bersamaan dengan ekstrak daun gedi $30 \mathrm{mg}$ selama 14 hari ditemukan ada beberapa bagian yang menunjukkan sedikit sel busa pada tunika intima dan tunika media. Sedangkan, pada kelompok tikus wistar yang diberikan lemak babi bersamaan dengan ekstrak daun gedi selama 28 hari, terdapat sedikit sel busa pada beberapa fokus di tunika intima dan tunika media. Keadaan ini sesuai dengan kepustakaan yang mengatakan bahwa kandungan antioksidan yaitu flavonoid yang terdapat dalam daun gedi mampu memberikan efek proteksi terhadap terbentuknya sel busa pada aorta. ${ }^{7}$ Senyawa flavonoid ini memberikan atom hidrogen pada rangkaian lipida sehingga bentuknya menjadi lebih stabil dan juga dapat menghambat atau mencegah reaksi autooksidasi lemak dan minyak termasuk LDL.

Pada kelompok tikus wistar yang diberikan diet lemak babi 2ml/hari kemudian dilanjutkkan dengan pemberian ekstrak daun gedi $30 \mathrm{mg}$ selama 7 hari, menunjukkan gambaran histopatologi aorta yang masih terdapat sel-sel busa pada bagian-bagian tertentu, namun jumlah sel busa tersebut lebih sedikit dibandingkan dengan kontrol positif. Menurut 
kepustakaan, daun gedi (Abelmoschus manihot L.) mengandung flavonoid yang berperan sebagai anti-oksidan yang dapat mereduksi LDL dan trigliserida, sehingga menghambat penumpukan LDL di dinding pembuluh darah. Daun gedi juga mengandung steroid yang terdiri dari fitosterol yang dapat menurunkan kadar kolesterol dan mempercepat ekskresi kolesterol. ${ }^{2,8}$ Asupan fitosterol yang terkandung dalam makanan mampu menghambat absorpsi kolesterol. Fitosterol yang mudah terhidrolisis, akan menurunkan kelarutan kolesterol sehingga absorpsi akan berkurang dan dapat meningkatkan ekskresi kolesterol. Fitosterol juga dapat bergabung dengan kolesterol membentuk kristal yang akan meningkatkan ekskresi kolesterol, sehingga dapat menurunkan kadar kolesterol plasma darah. Mekanisme inilah yang menjelaskan tentang berkurangnya jumlah sel busa pada aorta tikus kelompok perlakuan ini. Pemberian ekstrak daun gedi selama 7 hari telah menunjukan perubahan histologis namun belum optimal, hal ini mungkin dikarenakan oleh dosis yang belum optimal atau waktu penelitian yang tergolong singkat. ${ }^{9,10,11}$

\section{SIMPULAN}

Secara mikroskopik, aorta tikus wistar yang diberi lemak babi menunjukkan adanya penumpukan sel-sel busa pada tunika intima dan media, sedangkan pada aorta tikus wistar yang diberi lemak babi bersamaan dengan ekstrak daun gedi selama 14 dan 28 hari maupun pemberian lemak babi selama 14 dan 28 hari yang dilanjutkan dengan ekstrak daun gedi menunjukkan jumlah sel-sel busa yang lebih sedikit dibandingkan kontrol positif.

\section{SARAN}

1. Perlu dilakukan penelitian mengenai berbagai dosis pemberian ekstrak daun gedi untuk melihat dosis yang paling tepat.

2. Penelitian dengan waktu yang lebih panjang pada kelompok perlakuan yang diberikan lemak babi kemudian dilanjutkan dengan pemberian ekstrak daun gedi

3. Perlu dilakukan penghitungan jumlah sel busa secara kuantitatif pada seluruh penampang aorta.

\section{DAFTAR PUSTAKA}

1. Mamahit L. Satu Senyawa Steroid Dari Daun Gedi(Abelmoschus manihot L. Medik) Asal Sulawesi Utara. Fakultas Pertanian. UNSRAT.2009

2. Gani N, Momuat LI, Pitoi M. Profil Lipida Plasma Tikus Wistar yang Hiperkolesterolemia pada Pemberian Gedi Merah (Abelmoschus Manihot L.). Jurnal Mipa Unsrat Online.2013

3. Kumar, Cotran, Robbins. Robbins Basic Pathology. $7^{\text {th }}$ ed. Jakarta : Penerbit Buku Kedokteran EGC.2007. p:369-78.

4. Hermanto S, Muawanah A, Wardhani P. Profil dan Karakteristik Lemak Hewani (Ayam, Sapi dan Babi) Hasil Analisa FTIR dan GCMS. Program Studi Kimia.

5. Panjaitan FWF. Gambaran histologi aorta tikus wistar dengan diet lemak babi setelah pemberian ekstrak daun pepaya [skripsi]. [Manado (Indonesia)] : Universitas Sam Ratulangi;2013.

6. Mitchell RN, Schoen FJ. Blood Vessels. Dalam: Kumar, Abbas, Fausto, Aster. Robbins and Cotran Pathologic Basis of Disease. $8^{\text {th }}$ ed. Elsevier Saunders, 2010.

7. Agrawal AD. Pharmalogical Activities Of Flavonoids: A Review. Dalam : International Journal of Pharmaceutical Sciences and Nanotechnology.2011. 
8. MM Onakpa. Ethnomedicinal, phytochemical and pharmacological profile of genus Abelmoschus. Department of Veterinary Physiology and Biochemistry. University of Abuja Nigeria. Phytopharmacology.2013,4(3), 648-663.

9. Jain, P.S, Bari, S.B, Surana, S.J. Isolation of Stigmasterol and $\gamma$-Sitosterol from Petroleum Ether of Woody Stem of Abelmoschus manihot. Dalam : Asian Journal of Biological Sciences 2 (4): 112-117.2009

10. Marangoni F, Poli A. Phytosterols and cardiovascular health : A Review. Dalam : Pharmacological Research.2010.193-99.

11. Todorwal A, Jain P, Bari S. Abelmoschus manihot Linn : Ethobotany, Phytochemistry and Pharmacology. Dalam : Asian Journal of Traditional Medicines. 2011. 